Disclosure of Interests: Xenofon Baraliakos Grant/research support from: AbbVie, Boehringer Ingelheim, Bristol-Myers Squibb, Celgene, Centocor, Chugai, Janssen, MSD, Novartis, Pfizer Inc, Roche and UCB, Grant/ research support from: AbbVie, Pfizer, Merck Sharp \& Dohme, UCB Pharma, Novartis, Consultant for: AbbVie, Bristol-Myers Squibb, Boehringer Ingelheim, Celgene, Chugai, Janssen Biologics, Novartis, Pfizer, UCB Pharma, Galapagos, Speakers bureau: AbbVie, Chugai, Janssen, Novartis, Pfizer, UCB Pharma, Sebastian Kruse: None declared, Simone Auteri Employee of: Employee of UCB Pharma, Natasha de Peyrecave Employee of: Employee of UCB Pharma, Tommi Nurminen Employee of: Employee of UCB Pharma, Thomas Kumke Employee of: UCB Pharma, Bengt Hoepken Employee of: Employee of UCB Pharma, Juergen Braun Shareholder of: AbbVie, BMS, Celgene, Chugai, Merck, Novartis, Pfizer, UCB, Grant/research support from: AbbVie, BMS, Celgene, Chugai, Merck, Novartis, Pfizer, UCB, Grant/research support from: Abbott, Bristol Myers Squibb, Celgene, Celltrion, Chugai, Johnson \& Johnson, MSD, Novartis, Pfizer, Roche, UCB Pharma, Grant/research support from: AbbVie, BMS, Celgene, Chugai, Merck, Novartis, Pfizer, UCB, Grant/research support from: Abbvie (Abbott), Amgen, Baxter, Biogen, BMS, Boehringer, Celgene, Celltrion, Centocor, Chugai, Hexal, Janssen, Lilly, Medac, MSD (Schering-Plough), Mylan, Mundipharma, Novartis, Pfizer (Wyeth, Hospira), Roche, Sanofi-Aventis and UCB, Consultant for: Abbvie (Abbott), Amgen, Baxter, Biogen, BMS, Boehringer, Celgene, Celltrion, Centocor, Chugai, Hexal, Janssen, Lilly, Medac, MSD (Schering-Plough), Mylan, Mundipharma, Novartis, Pfizer (Wyeth, Hospira), Roche, Sanofi-Aventis and UCB, Consultant for: AbbVie, BMS, Celgene, Chugai, Merck, Novartis, Pfizer, UCB, Consultant for: Abbott, Bristol Myers Squibb, Celgene, Celltrion, Chugai, Johnson \& Johnson, MSD, Novartis, Pfizer, Roche, UCB Pharma, Speakers bureau: AbbVie, BMS, Celgene, Chugai, Merck, Novartis, Pfizer, UCB, Speakers bureau: Abbvie (Abbott), Amgen, Baxter, Biogen, BMS, Boehringer, Celgene, Celltrion, Centocor, Chugai, Hexal, Janssen, Lilly, Medac, MSD (Schering-Plough), Mylan, Mundipharma, Novartis, Pfizer (Wyeth, Hospira), Roche, Sanofi-Aventis and UCB, Speakers bureau: AbbVie, BMS, Celgene, Chugai, Merck, Novartis, Pfizer, UCBDOI: 10.1136/annrheumdis-2019-eular.689

\section{FRI0386 RELATIONSHIP BETWEEN ASDAS STATES AND INHIBITION OF STRUCTURAL DAMAGE PROGRESSION WITH SECUKINUMAB IN ANKYLOSING SPONDYLITIS: DATA FROM MEASURE 1 TRIAL}

Xenofon Baraliakos ${ }^{1}$, Helena Marzo-Ortega ${ }^{2}$, Filip van den Bosch ${ }^{3}$, Atul Deodhar ${ }^{4}$, Erhard Quebe-Fehling ${ }^{5}$, Eumorphia Maria Delicha ${ }^{5}$, Zsolts Talloczy, Corine Gaillez ${ }^{5}$. 1 Rheumazentrum Ruhrgebiet, Ruhr University Bochum, Herne, Germany; ${ }^{2}$ NIHR LBRC, Leeds Teaching Hospitals Trust and LIRMM, Unversity of Leeds, Leeds, United Kingdom; ${ }^{3}$ Ghent University Hospital, Ghent, Belgium; ${ }^{4}$ Oregon Health and Science University, Oregon, United States of America; ${ }^{5}$ Novartis Pharma AG, Basel, Switzerland; ${ }^{6}$ Novartis Pharmaceuticals Corporation, East Hanover, United States of America

Background: The primary treatment goal in patient with axial Spondyloarthritis $(\mathrm{axSpA})$ is to optimize health-related quality of life through control of signs and symptoms, no structural damage progression and preservation of function. ${ }^{1}$ The 2017 Treat to Target recommendations (T2T) outlined Ankylosing Spondylitis Disease Activity Score (ASDAS) -inactive disease (ID) as an optimal treatment target for axSpA patients. ${ }^{1}$ ASDAS states were shown to correlate with syndesmophyte formation as assessed with X-Ray and MRI changes. ${ }^{2}$ Secukinumab, a fully human monoclonal antibody that directly inhibits IL-17A, demonstrated sustained efficacy and low radiographic progression through 4 years in patient with ankylosing spondylitis (AS) in MEASURE 1 study (NCT01863732). ${ }^{3}$

Objectives: To investigate the relationship between ASDAS states and inhibition of radiographic structural progression in patient with AS treated with secukinumab $150 \mathrm{mg}$ from the MEASURE 1 study over 4-years using post hoc analysis.

Methods: Lateral radiographs of the cervical and lumbar spine were assessed using the modified Stoke Ankylosing Spondylitis Spinal Score (mSASSS: range 0-72). Images were scored twice at baseline/Week (Wk) 104 and baseline/Wk 208 by 2 central readers blinded to treatment/visit; mean change from baseline to Wk 104 or 208 in mSASSS scores were used. The ASDAS-CRP was used to define the disease activity states at Wks 16, 52, 104, and 208: ID (ASDAS-CRP < 1.3), Low Disease Activity (LDA, $1.3 \leq$ ASDAS-CRP $<2.1)$ or pooled High/Very High Disease
Activity (HDA/VHDA, ASDAS-CRP $\geq 2.1$ ) given low number of patients with VHDA. Sustained ASDAS state at Wk 104 was defined as reaching the same state at Wk 104 and Wk 16 and/or 52. Sustained ASDAS state at Wk 208 was defined as reaching the same state at Wk 208 and Wk 16 and/or 52. Overall, 87 patients on secukinumab $150 \mathrm{mg}$ were in the extension trial; of these, 57 and 71 , respectively, had evaluable X-rays at Wks 104 and 208.

Results: The proportion of patients achieving each ASDAS state are shown in Table. Patients with ASDAS-ID were associated with numerically lower mSASSS mean change from baseline to Wks 104/208 compared to other ASDAS states (Figure).

Conclusion: In this post hoc analysis, patients with ASDAS-ID state and sustained ASDAS-ID state had lower radiographic progression than patients with higher disease activity at 2 and 4 -years suggesting a potential relationship between ASDAS state and structural progression in patients with AS. Further confirmation is needed in larger prospective studies.

\section{REFERENCES:}

[1] Smolen JS, et al. Ann Rheum Dis. 2018;77:3-17.

[2] Poddubnyy D, et al. Ann Rheum Dis. 2014;73:422.

[3] Braun J, et al. Rheumatology (Oxford) 2018. Doi: 10.1093/rheumatology/ key375.

Table: Proportion of Patients with ASDAS States through Wk 208

\begin{tabular}{lcccc}
\hline ASDAS states & Wk $\mathbf{1 6}$ & Wk $\mathbf{5 2}$ & Wk 104 & Wk 208 \\
& $\mathbf{N}=\mathbf{8 6}$ & $\mathbf{N}=\mathbf{8 4}$ & $\mathbf{N}=\mathbf{8 0}$ & $\mathbf{N}=\mathbf{7 8}$ \\
\hline ID & 24.4 & 25.0 & 30.0 & 26.9 \\
LDA & 34.9 & 39.3 & 38.8 & 33.3 \\
HDA/VHDA & 40.7 & 35.7 & 31.3 & 39.7
\end{tabular}

ID, Inactive Disease (ASDAS-CRP < 1.3); LDA, Low Disease Activity $(1.3 \leq$ ASDAS-CRP $<$ 2.1); HDA/VHDA, High/very high Disease Activity (ASDAS-CRP $\geq 2.1$ )

$\mathrm{N}$, total number patients with ASDAS

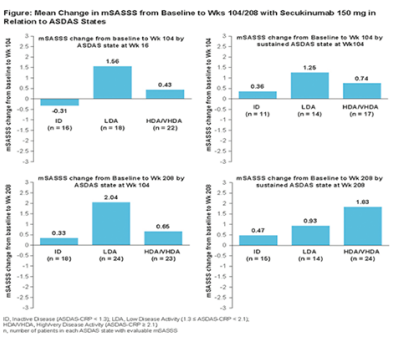

Disclosure of Interests: Xenofon Baraliakos Grant/research support from: AbbVie, Boehringer Ingelheim, Bristol-Myers Squibb, Celgene, Centocor Chugai, Janssen, MSD, Novartis, Pfizer Inc, Roche and UCB, Grant/ research support from: AbbVie, Pfizer, Merck Sharp \& Dohme, UCB Pharma, Novartis, Consultant for: AbbVie, Bristol-Myers Squibb, Boehringer Ingelheim, Celgene, Chugai, Janssen Biologics, Novartis, Pfizer, UCB Pharma, Galapagos, Speakers bureau: AbbVie, Chugai, Janssen, Novartis, Pfizer, UCB Pharma, Helena Marzo-Ortega Grant/research support from: Janssen, Novartis and Pfizer, Consultant for: AbbVie, Celgene, Janssen, Eli-Lilly, Novartis and UCB, Speakers bureau: AbbVie, Celgene, Janssen, Eli-Lilly, Novartis and UCB, Filip van den Bosch Consultant for: AbbVie BMS, Galapagos, Janssen, Lilly, Merck, Novartis, Pfizer and UCB, Speakers bureau: AbbVie, BMS, Janssen, Lilly, Merck, Novartis, Pfizer and UCB., Atul Deodhar Grant/research support from: AbbVie, Amgen, El Lilly, GSK, Janssen, Novartis, Pfizer, and UCB, Consultant for: AbbVie, Amgen, BMS, Eli Lilly, Janssen, Novartis, Pfizer, and UCB, Erhard Quebe-Fehling Shareholder of: Novartis, Employee of: Novartis, Eumorphia Maria Delicha Employee of: Novartis, Zsolts Talloczy Shareholder of: Novartis, Employee of: Novartis, Corine Gaillez Shareholder of: Novartis, BMS, Employee of: Novartis

DOI: 10.1136/annrheumdis-2019-eular.1255 